\title{
A Wise Move
}

\section{BILL MONCUR, Boissevain, Manitoba}

I think it is a wise move for the Archaeological Society to join with the Saskatchewan Natural History Society and to operate as one group. Those of us interested in archaeology generally have a real interest in the early history of our plains.

Besides collecting relics, I have gathered history of the early days in the Turtle Mountain area through interviewing pioneers, collecting stories of their early day experiences, so I am pleased at the move the two societies have made.

\section{Mutual Assistance}

"While we are grateful for the commercial and industrial prosperity Canada is experiencing. it is essential for the well-being of future generations that cultural interests by continued development influence and help the public generally.

I have found the "Spade and Screen" very interesting and informative and hope the amalgamation of the two societies will be of assistance to both."

REV. G. H. RALEY, Vancouver.

\section{Historic Sites}

By A. M. PROVICK, Hazelcliffe

It is gratifying to those of us who are interested in Western history and historic sites, that we now have an Historic Sites Board, under the direction of Mr. J. D. Herbert, M.A.

We should have had the services of an Historic Sites Supervisor many years ago, I believe, as many sites are little more than just that. I am personally very interested in the postal history of Saskatchewan, and I think there would have been a splendid opportunity until recently, of photographing many of the old post offices opened while this area was North West Territories and later Assinibcia. Many of the original postmasters could have been interviewed as well and a wealth of interesting information obtained.

There is still time, however, to do some work in this direction. Just recently I had the opportunity to visit the farm of $\mathrm{Mr}$. Charles Sandeen, of Stockholm. On his farm and still in use is the original Ohlen post office shack, built in 1886 . The post office was opened in 1887 and it is of interest to note that the original post office sign is still tacked up over the old doorway, although in poor condition.
There is also, near here, an original post office in much better condition, although opened as Tantallon Assa. some ten years later than Ohlen. This is now the home of Peter Arnason, of Tantallon, and once the huge mansion belonging to Senator Thomas Douglas. Only half of the original remains but it is still big enough to get lost in.

It is granted that old post office sites are not, by any means, as interesting or historic as old forts or trading posts, but nevertheless we should not neglect the opportunity, however late it may be, of recording and marking as many as possible for future generations.

I have had the idea that a loose knit organization of persons in this province interested in local history, be formed, with the object of helping our provincial and federal boards in their work, as well as for individual amusement.

I remember seeing a letter in the "Blue Jay" from Mr. Campbell Innes about Historic Sites and would be pleased to hear from him if he is interested in the Postal History of Saskatchewan. 